\title{
RELIABILITY OF AN ISOMETRIC TEST FOR MEASURING THE STRENGTH OF THE HIP ABDUCTORS AND ADDUCTORS
}

\author{
CONFIABILIDADE DE UM TESTE ISOMÉTRICO PARA MEDIR A FORÇA DE \\ ABDUTORES E ADUTORES DE QUADRIL
}

\section{Manoella Regina de Souza SILVA ${ }^{1}$; Thiago Keitiney Souza Teixeira DA SILVA²; Valdemi Xavier DELMONDES JUNIOR ${ }^{3}$; Silvia Ribeiro Santos ARAÚJO ${ }^{4}$; Adriano Percival Calderaro CALVO ${ }^{5}$; Jacielle Carolina FERREIRA ${ }^{6}$}

1. Physical Educator and member of Research Group of Biomechanics Applied to Sport Training - GPBATE, Cuiabá, MT, Brazil. manucba@gmail.com; 2. Physical Educator. Cuiabá, MT, Brazil; 3. Physical Educator, Cuiabá, MT, Brazil; 4. PhD in Sports Sciences, Professor of Physical Education at Federal University of Minas Gerais, Belo Horizonte, MG, Brazil; 5. PhD in Sciences, Professor of Physical Education at Air Force University - UNIFA, Rio de Janeiro, RJ, Brazil; 6. PhD in Sports Sciences, Professor of Physical Education and Strictu Sensu Postgraduate Program in Physical Education at UFMT and coordinator of GPBATE, Cuiabá, MT, Brazil.

\begin{abstract}
This study aimed to measure the reliability of a test for measuring the strength and strength imbalance of the hip abductors and adductors, using isokinetic equipment adapted for isometric testing. Thirteen healthy, physically active male individuals took part in the research. Two unilateral isometric tests were undertaken using a load cell attached to an adapted abductor bench machine: a hip abduction test and hip adduction test. Tests consisted of two maximum voluntary isometric contractions made for six seconds with a break of one minute between each. The following dynamic variables were measured: maximum force, mean force, rate of force development for each limb (right and left), and the existence of asymmetries between the limbs. For statistical analysis, the t-test, intraclass correlation coefficient (ICC), and standard error of measurement (SEM) were applied. Results: The methodology utilized for the evaluation of the hip abductors and adductors did not show reliability in most of the parameters researched, with the ICC neither sufficient or low, and the retest performance higher than the test $(\mathrm{p}<0.05)$. The applied test was not reliable for assessing strength and strength imbalances of hip abductors and adductors in most of the parameters investigated. These results indicate that the hip joints, more precisely, the abductor and adductor muscles, are complex structures to be assessed. They need to be previously familiarized with the proposed exercise, as their performance does not occur habitually. It is recommended to develop new tests in order to measure hip abduction and adduction strength adding a prior familiarization procedure.
\end{abstract} Coefficient.

KEYWORDS: Isometry. Load Cell. Muscle Strength Dynamometer. Intraclass Correlation

\section{INTRODUCTION}

Muscle imbalances are alterations in the recruitment of one or more muscles in a given movement, which can generate dysfunction and contribute to the emergence of functionally disabling pathologies (SAHRMANN, 2002). These changes may occur either between agonists and antagonists or between the dominant and nondominant limbs, and are among the reasons mentioned in the literature as potential causes of muscular injuries and decreases in performance (MAGALHÃES et al., 2004).

It is known that strength imbalance acts statically and dynamically over joints and may surge as a result of the standard of use in daily activities and sports, resulting from developing a specific musculature according to the overload applied. These muscular specializations might initiate posture and mechanical joint changes, in addition to overloading musculo tendinous structures around the joints (PANNI et al., 2002; SIQUEIRA et al., 2002). Besides the imbalance of strength on the same joint (agonist-antagonist), there is the imbalance that affects the homologous limbs (rightleft), commonly named as lateral asymmetry of strength. This type of imbalance is linked specifically to side preference, a human characteristic understood as the predisposition to choosing a limb in relation to the homologous contralateral to perform motor actions (WITVROUW et al., 2003).

Lateral asymmetry is present in almost every movement we perform daily and is defined as side-to-side differences in strength, flexibility, mobility and neural control (MITCHELL et al., 2016). McCurdy et al. (2006) suggest that one of the causes of these discrepancies is performances that 
require repetitive and asymmetric use of these limbs, clearly noticed in sportive performances, where the athletes hardly have an equal output between sides.

In order to measure and evaluate the levels of strength and strength imbalance, computerized dynamic isokinetic dynamometer have been considered reliable (ALVARES et al., 2015), however, as it has a high cost and is less accessible for most professionals in the health area. Looking toward alternatives, some studies have shown that dynamometers are a good option to replace the isokinetic dynamometer. Martin et al. (2006) showed good agreement in the evaluation of the strength of the knee extensor musculature of geriatric patients, and Vasconcelos et al. (2009) concluded that the analog isometric dynamometer adapted mechanotherapy equipment has the capacity of measuring the deficits of the flexor and extensor knee muscles. This research, nevertheless, point to a good reliability of isometric dynamometers to measure the strength of the lower limbs using evaluation of the knee joint, while no research that comes up with data about the reliability of hip adduction and abduction has been found (MARTIN et al., 2006; VASCONCELOS et al., 2009).

Despite the lack of information about the reliability of the measures of isometric dynamometers for the evaluation of the hip joint, this kind of instrument has been used in research for hip abductor strength evaluation (BITTENCOURT et al., 2016; TEIXEIRA-SALMELA et al., 2005). Teixeira-Salmela et al. (2005) report that chronic hemiplegic individuals had a gain of strength of the hip abductors either for the affected limb (pre: $104.95 \pm 47.34$ - post: $127.91 \pm 57.31-25 \%$ gain) or for the non-affected limb (pre: $128.17 \pm 46.35-$ post: $153.17 \pm 45.04-29 \%$ gain), using a manual dynamometer, while Bittencourt et al. (2016) established reference values for the maximum isometric torque of the hip abductors in young athletes using a manual dynamometer. However, it should be noted that both studies have not reported information about the reliability of the measures, which might prove a limitation for research using this method of evaluation, and also for the practical/clinical application of tests involving the acts of hip adduction and abduction.

Considering the lack of methods for measuring hip adductor and abductor strength with test reliability, and the importance of the reliability assessment of the methods of strength and strength imbalance measuring for scientific or clinical use, the presented study had the goal of measuring the reliability of a test to measure the strength and the strength imbalance of hip abductors and adductors using isoinertial equipment adapted for isometric testing.

\section{MATERIAL AND METHODS}

\section{Participants and ethical concerns}

For this research, 13 healthy, physically active and practitioners of resistance training for more than 6 months males took part. The inclusion criteria included: being aged between 18 and 45 years old; practicing resistance training at least twice a week for more than six months; not having any kind of functional limitation for the execution of the proposed tests. The volunteers answered an anamnesis and two other forms in order to classify their level of physical activity and measure their readiness for physical activity (IPAQ - short version and PAR-Q, respectively).

All the volunteers received explanations about the experimental procedures and their implications; they also signed a clarified and free consent form. This research followed all the current recommendations for research with human beings and was approved by the local ethics committee in research (n. 1.719.456).

\section{Procedures}

The tests were completed over two weeks. The volunteers were instructed not to train exhaustively 24 hours before undertaking the tests and attend the two days of testing fed and hydrated. The data collecting consisted of unilateral isometric tests for the lower limbs using a load cell (EMG System do Brasil®, model TS, $200 \mathrm{~kg}$ maximum capacity), attached to an abductor bench machine (Pirajuß), also adapted to permit adduction, both unilaterally.

Two unilateral isometric tests were taken: a hip abduction test (AB) and hip adduction test (AD). In order to minimize the fatigue effect and execution order, the tests were conducted on two different days, with at least a 48 hour break between them, in a random order. For randomization, the volunteer raffled the test and the leg on which he would start the procedures. To try to approximate balancing, the next volunteer would start the procedure in reverse order. The same procedures were repeated with a break of at least seven days in pursuance of testing the reliability, completing four experimental sessions. In the retest, each volunteer followed the same order of procedures performed in the test. During all the tests, two maximum voluntary isometric contractions were made for six seconds with a break of one minute between each. Before the 
Reliability of an isometric...

tests, the volunteers had a session of five minutes warm up cycling on an ergometric bicycle.

An isoinertial adductor bench machine was modified for the research, turning it into an isometric abductor and adductor, which had a load cell attached in order to obtain the strength values (Figure 1a). The volunteers' posture performing the exercise was seated with the upper body straight and adjusted by the seatback to allow a $90^{\circ}$ hip articulation flexion angle and $90^{\circ}$ at the knee joint. The angulation was $0^{\circ}$ for the beginning of the hip adduction movement. A mark on the bench machine helped when positioning the volunteers, either to the left or to the right side.

For the hip abduction the volunteer was positioned in the middle of the bench. The maintenance of the posture for the upper body, legs, and feet was made using fixing straps. For AB and $\mathrm{AD}$, the upper body was fixed on the seatback by the straps forming an " $X$ " and the hands kept crossed on the chest, so they could not interfere in the performance. For AB, the foot and knee of the limb supposed to perform was positioned on the equipment's pedal and fixed with fixing straps, while the other foot was fixed on the equipment's console, so it could not interfere with the other limb moving (Figure 1b). For AD, the volunteer was seated on a mark indicating $0^{\circ}$ angulation (for the right hip adduction, the volunteer was seated on the
SILVA et al.

equipment's left side, and for the left hip adduction, the volunteer was seated on the right side), and the foot supposed to perform the movement was positioned on the equipment's pedal, and either, foot and knee were attached by fixing straps. The foot of the limb which was not performing the movement was positioned on an auxiliary platform (Figure 1c). The load cell was calibrated before the experiment and the frequency of signal data acquirement was $200 \mathrm{~Hz}$, with signal acquirement by Software $\mathrm{EMGLab}^{\circledR}$.

Matlabß Software was used for treating the signal and analysis of the following dynamic variables: 1) maximum force $\left(\mathrm{F}_{\mathrm{MAX}}\right)$, defined as the strongest the neuromuscular system can mobilize through a voluntary maximum contraction; 2) mean force $\left(\mathrm{F}_{\text {MEAN }}\right)$ considering the strength average throughout five seconds; and 3) rate of force development (RFD), which according to Haff et al. (2015), is defined as the increase of the strength rate in a certain time gap at the beginning of the muscular contraction. The current research identified the major strength variation in a gap of $100 \mathrm{~ms}$ for each limb $(\mathrm{R}=$ right; $\mathrm{L}=1 \mathrm{eft})$. The asymmetries were calculated from these variables, as the percentage difference in strength between the weaker limb and stronger limb (FERREIRA et al., 2018), and the adductor and abductor (adductor/abductor) strength ratios.
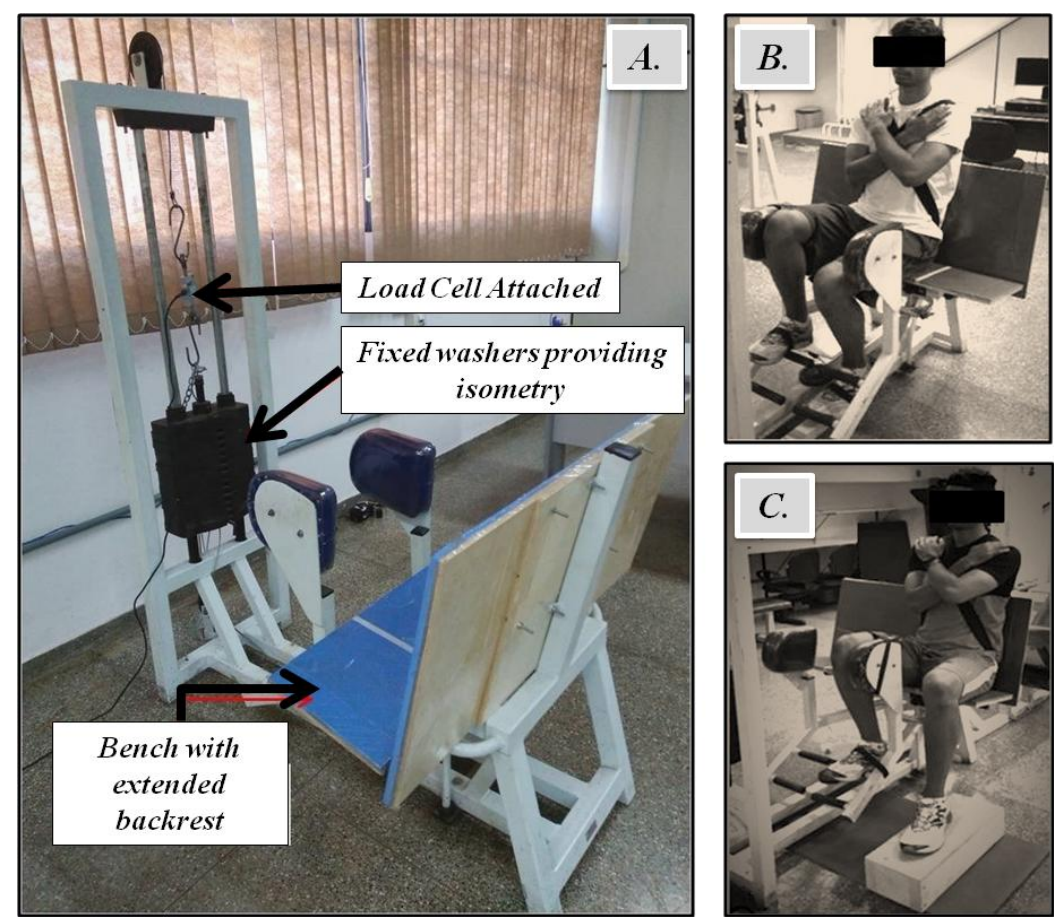

Figure 1. A- Modified isoinertial bench machine for this experiment. B- Execution of the hips abduction test. C- Execution of the hips adduction. 


\section{Statistics analysis}

The data analysis was made using descriptive and inferential statistics. The data are expressed as averages and standard deviations. The normality of the data distribution was tested through the Shapiro-Wilk test. A paired t-test was used to compare between the test and retest average. The intraclass correlation coefficient (ICC) was calculated in order to evaluate the reliability of the instrument through the test-retest. The standard error of measurement (SEM), absolute and relative, estimated the variability among the sampling averages. A significance level of $p<0.05$ was adopted. The statistic package used was SigmaStat $($ v. 3.5 .

\section{RESULTS}

The descriptive data of participant characteristics are reported in Table 1 and the inferential analysis is reported in Table 2. The descriptive data of dependent variables contain the average and dispersion values of all the measured variables for the test and retest, as well as the absolute differences between test and retest.

Table 1. Participants characteristics.

\begin{tabular}{lcccc}
\hline & Mass & Heigth & Age & IPAQ \\
& $(\mathrm{Kg})$ & $(\mathrm{m})$ & (years) & (METs/week) \\
Mean & 75,79 & 1,79 & 26,32 & 6857,28 \\
$( \pm$ Standard deviation) & $( \pm 9,30)$ & $( \pm 0,06)$ & $( \pm 5,28)$ & $( \pm 8977,24)$ \\
\hline
\end{tabular}

There was a significant difference between test and retest in the following variables: right $\mathrm{AB}$ $\left(\mathrm{AB}_{\mathrm{R}}\right) \mathrm{F}_{\text {MEAN }}(\mathrm{p}<0.01)$, left $\mathrm{AB}\left(\mathrm{AB}_{\mathrm{L}}\right) \mathrm{F}_{\mathrm{MAX}}(\mathrm{p}<$ $0.02), \mathrm{AB}_{\mathrm{L}} \mathrm{F}_{\text {MEAN }}(\mathrm{p}<0.01), \mathrm{AB}$ asymmetry $\left(\mathrm{AB}_{\mathrm{A}}\right)$ $\mathrm{F}_{\mathrm{MAX}}(\mathrm{p}<0.05)$, and $\mathrm{AB}_{\mathrm{A}} \mathrm{F}_{\text {MEAN }}(\mathrm{p}<0.03)$. According to the ICC results, only the following variables reported moderate reliability: $A B_{R} F_{M A X}$ $(\mathrm{ICC}=0.48), \mathrm{AB}_{\mathrm{R}} \mathrm{F}_{\mathrm{MEAN}}(\mathrm{ICC}=0.55), \mathrm{AB}_{\mathrm{L}} \mathrm{F}_{\mathrm{MAX}}$ $(\mathrm{ICC}=0.71), \mathrm{AB}_{\mathrm{L}} \mathrm{F}_{\text {MEAN }}(\mathrm{ICC}=0.52), \mathrm{AD}_{\mathrm{R}} \mathrm{RFD}$
$(\mathrm{ICC}=0.46)$, and $\mathrm{AD}$ asymmetry $\left(\mathrm{AD}_{\mathrm{A}}\right) \mathrm{F}_{\mathrm{MEAN}}$ $(\mathrm{ICC}=0.66)$.

The SEM was calculated in order to estimate the sampling average. The variables that reported the lowest levels in relative SEM were: $A B_{R} F_{M A X}, A B_{L} F_{M E A N}, A D_{R} F_{M A X}$, left ADL $\left(A D_{L}\right)$ $F_{\text {MAX }}, A_{D} / A_{D} F_{\text {MEAN }}, A_{\mathrm{L}} / A B_{L} F_{\text {MAX }}, A_{A} F_{\text {MAX }}$, and $\mathrm{AD}_{\mathrm{A}} \mathrm{F}_{\mathrm{MAX}}$. The RFD was the variable with the higher SEM.

Table 2. Descriptive and inferential results of the strength evaluation of hip adductors and abductors

\begin{tabular}{|c|c|c|c|c|c|c|c|c|}
\hline & Variables & Test & Re-test & Difference & $p$ & ICC & SEM & SEM [\%] \\
\hline \multirow{3}{*}{$\mathrm{AB}_{\mathrm{R}}$} & $\mathrm{F}_{\mathrm{MAX}}[\mathrm{kgf}]$ & $\begin{array}{l}62,24 \\
( \pm 12,45)\end{array}$ & $\begin{array}{l}72,80 \\
( \pm 11,97)\end{array}$ & $\begin{array}{l}10,56 \\
( \pm 10,56)\end{array}$ & 0,09 & 0,48 & 6,88 & 12,16 \\
\hline & $\mathrm{F}_{\text {MEAN }}[\mathrm{kgf}]$ & $\begin{array}{l}50,44 \\
( \pm 11,97)\end{array}$ & $\begin{array}{l}61,63 \\
( \pm 11,93)\end{array}$ & $\begin{array}{l}11,19 \\
( \pm 0,04)\end{array}$ & $0,01^{*}$ & 0,55 & 6,36 & 12,74 \\
\hline & RFD [kgf/s] & $\begin{array}{l}290,06 \\
( \pm 172,60)\end{array}$ & $\begin{array}{l}307,29 \\
( \pm 165,07)\end{array}$ & $\begin{array}{l}17,23 \\
( \pm 7,53)\end{array}$ & 0,77 & N.S. & 108,06 & 40,89 \\
\hline \multirow{3}{*}{$\mathrm{AB}_{\mathrm{L}}$} & $\mathrm{F}_{\mathrm{MAX}}[\mathrm{kgf}]$ & $\begin{array}{l}57,99 \\
( \pm 15,06)\end{array}$ & $\begin{array}{l}69,49 \\
( \pm 13,16)\end{array}$ & $\begin{array}{l}11,50 \\
( \pm 1,90)\end{array}$ & $0,02 *$ & 0,71 & 6,71 & 12,09 \\
\hline & $\mathrm{F}_{\text {MEAN }}[\mathrm{kgf}]$ & $\begin{array}{l}48,13 \\
( \pm 13,29)\end{array}$ & $\begin{array}{l}59,39 \\
( \pm 12,11)\end{array}$ & $\begin{array}{l}11,26 \\
( \pm 1,18)\end{array}$ & $0,01^{*}$ & 0,52 & 5,27 & 10,74 \\
\hline & RFD [kgf/s] & $\begin{array}{l}240,88 \\
( \pm 133,71)\end{array}$ & $\begin{array}{l}252,70 \\
( \pm 119,35)\end{array}$ & $\begin{array}{l}11,82 \\
( \pm 14,36)\end{array}$ & 0,49 & N.S. & 138,2 & 57,48 \\
\hline \multirow{3}{*}{$\mathrm{AD}_{\mathrm{R}}$} & $\mathrm{F}_{\mathrm{MAX}}[\mathrm{kgf}]$ & $\begin{array}{l}29,80 \\
( \pm 12,83)\end{array}$ & $\begin{array}{l}35,97 \\
( \pm 9,84)\end{array}$ & $\begin{array}{l}6,17 \\
( \pm 2,99)\end{array}$ & 0,10 & N.S. & 4,12 & 2,44 \\
\hline & $\mathrm{F}_{\text {MEAN }}[\mathrm{kgf}]$ & $\begin{array}{l}20,76 \\
( \pm 11,18)\end{array}$ & $\begin{array}{l}24,64 \\
( \pm 7,63)\end{array}$ & $\begin{array}{l}3,88 \\
( \pm 3,55)\end{array}$ & 0,34 & N.S. & 4,15 & 14,23 \\
\hline & RFD [kgf/s] & $\begin{array}{l}157,36 \\
( \pm 82,00)\end{array}$ & $\begin{array}{l}146,54 \\
( \pm 59,12)\end{array}$ & $\begin{array}{l}10,82 \\
( \pm 22,88)\end{array}$ & 0,58 & 0,46 & 29,7 & 22,64 \\
\hline \multirow{2}{*}{$\mathrm{AD}_{\mathrm{L}}$} & $\mathrm{F}_{\mathrm{MAX}}[\mathrm{kgf}]$ & $\begin{array}{l}32,20 \\
( \pm 14,25)\end{array}$ & $\begin{array}{l}33,38 \\
( \pm 13,09)\end{array}$ & $\begin{array}{l}1,18 \\
( \pm 1,16)\end{array}$ & 0,39 & N.S. & 5,44 & 17,18 \\
\hline & $\mathrm{F}_{\text {MEAN }}[\mathrm{kgf}]$ & $\begin{array}{l}22,48 \\
( \pm 11,18)\end{array}$ & $\begin{array}{l}23,42 \\
( \pm 10,33)\end{array}$ & $\begin{array}{l}0,94 \\
( \pm 0,85)\end{array}$ & 0,92 & N.S. & 5,37 & 19,34 \\
\hline
\end{tabular}




\begin{tabular}{|c|c|c|c|c|c|c|c|c|}
\hline & RFD [kgf/s] & $\begin{array}{l}182,89 \\
( \pm 89,19)\end{array}$ & $\begin{array}{l}174,46 \\
( \pm 63,90)\end{array}$ & $\begin{array}{l}8,43 \\
( \pm 25,29)\end{array}$ & 0,50 & N.S. & 45,52 & 38,11 \\
\hline \multirow{3}{*}{$\mathrm{AD}_{\mathrm{R}} / \mathrm{AB}_{\mathrm{R}}$} & $\mathrm{F}_{\mathrm{MAX}}$ & $\begin{array}{l}0,48 \\
( \pm 0,16)\end{array}$ & $\begin{array}{l}0,50 \\
( \pm 0,15)\end{array}$ & $\begin{array}{l}0,02 \\
( \pm 0,01)\end{array}$ & 0,39 & N.S. & 0,1 & 16,34 \\
\hline & $\mathrm{F}_{\text {MEAN }}$ & $\begin{array}{l}0,40 \\
( \pm 0,16)\end{array}$ & $\begin{array}{l}0,41 \\
( \pm 0,15)\end{array}$ & $\begin{array}{l}0,01 \\
( \pm 0,01)\end{array}$ & 0,92 & N.S. & 0,09 & 15,7 \\
\hline & RFD & $\begin{array}{l}0,65 \\
( \pm 0,37)\end{array}$ & $\begin{array}{l}0,55 \\
( \pm 0,23)\end{array}$ & $\begin{array}{l}0,10 \\
( \pm 0,14)\end{array}$ & 0,50 & N.S. & 0,24 & 40,79 \\
\hline \multirow{3}{*}{$\mathrm{AD}_{\mathrm{L}} / \mathrm{AB}_{\mathrm{L}}$} & $\mathrm{F}_{\mathrm{MAX}}$ & $\begin{array}{l}0,56 \\
( \pm 0,21)\end{array}$ & $\begin{array}{l}0,50 \\
( \pm 0,22)\end{array}$ & $\begin{array}{l}0,06 \\
( \pm 0,01)\end{array}$ & 0,55 & N.S. & 0,1 & 16,09 \\
\hline & $\mathrm{F}_{\text {MEAN }}$ & $\begin{array}{l}0,47 \\
( \pm 0,19)\end{array}$ & $\begin{array}{l}0,42 \\
( \pm 0,20)\end{array}$ & $\begin{array}{l}0,05 \\
( \pm 0,01)\end{array}$ & 0,67 & N.S. & 0,1 & 17,53 \\
\hline & RFD & $\begin{array}{l}1,08 \\
( \pm 0,39)\end{array}$ & $\begin{array}{l}0,90 \\
( \pm 0,64)\end{array}$ & $\begin{array}{l}0,18 \\
( \pm 0,25)\end{array}$ & 0,89 & N.S. & 1,07 & 139,15 \\
\hline \multirow{3}{*}{$\mathrm{AB}_{\mathrm{A}}$} & $\mathrm{F}_{\mathrm{MAX}}[\%]$ & $\begin{array}{l}15,04 \\
( \pm 10,29)\end{array}$ & $\begin{array}{l}10,87 \\
( \pm 5,83)\end{array}$ & $\begin{array}{l}4,17 \\
( \pm 4,46)\end{array}$ & $0,05^{*}$ & N.S. & 7,92 & 79,12 \\
\hline & $\mathrm{F}_{\text {MEAN }}[\%]$ & $\begin{array}{l}16,06 \\
( \pm 10,34)\end{array}$ & $\begin{array}{l}11,28 \\
( \pm 8,24)\end{array}$ & $\begin{array}{l}4,78 \\
( \pm 2,10)\end{array}$ & $0,03 *$ & N.S. & 5,66 & 54,42 \\
\hline & RFD [\%] & $\begin{array}{l}34,96 \\
( \pm 22,75)\end{array}$ & $\begin{array}{l}22,03 \\
( \pm 18,02)\end{array}$ & $\begin{array}{l}12,93 \\
( \pm 4,73) \\
\end{array}$ & 0,36 & N.S. & 14,56 & 57,6 \\
\hline \multirow{3}{*}{$\mathrm{AD}_{\mathrm{A}}$} & $\mathrm{F}_{\mathrm{MAX}}[\%]$ & $\begin{array}{l}21,72 \\
( \pm 15,55)\end{array}$ & $\begin{array}{l}19,75 \\
( \pm 16,83)\end{array}$ & $\begin{array}{l}6,17 \\
( \pm 1,28)\end{array}$ & 0,73 & N.S. & 11,74 & 82,05 \\
\hline & $\mathrm{F}_{\text {MEAN }}[\%]$ & $\begin{array}{l}25,81 \\
( \pm 20,20)\end{array}$ & $\begin{array}{l}26,16 \\
( \pm 16,98)\end{array}$ & $\begin{array}{l}0,35 \\
( \pm 3,22)\end{array}$ & 0,21 & 0,66 & 12,07 & 83,37 \\
\hline & RFD [\%] & $\begin{array}{l}26,65 \\
( \pm 23,66)\end{array}$ & $\begin{array}{l}29,11 \\
( \pm 18,69)\end{array}$ & $\begin{array}{l}2,46 \\
( \pm 4,97)\end{array}$ & 0,31 & N.S. & 18,57 & 91,38 \\
\hline
\end{tabular}

Note: $\mathrm{p}=$ paired $\mathrm{t}$ test result; $\mathrm{ICC}=$ Intraclass Correlation Coefficient; $\mathrm{SEM}=$ Standard Error of Measurement; $\mathrm{AB}_{\mathrm{R}}=$ right hip abduction test; $A B_{L}=$ left hip abduction test; $A D_{R}=$ right hip adduction test; $A D_{L}=$ left hip adduction test; $A D_{R} / A_{R}=$ adduction / abduction ratio of right hip; $\mathrm{AD}_{\mathrm{L}} / \mathrm{AB}_{\mathrm{L}}=$ adduction / abduction ratio of left hip; $\mathrm{AB}_{\mathrm{A}}=$ hip abductors asymmetry; $\mathrm{AD}_{\mathrm{A}}=$ hip adductors asymmetry; N.S. $=$ Non significative; $\mathrm{p}<0,05^{*}$.

\section{DISCUSSION}

This research had the aim of evaluating the reliability of a test for measuring the strength and strength imbalance of hip abductors and adductors using isoinertial equipment adapted for isometrics. The results obtained indicate a low reliability of the test procedures adopted. Only the variables $\mathrm{AB}_{\mathrm{L}}$ $F_{M A X}$, and $A D_{R} R F D$ came up with significant ICCs and had no performance increase between test and retest. The other variants reported non-significant ICCs and/or a performance increase between test and retest, in addition to high SEM values.

The low reliability found for the measurements in this research may be associated with the fact that the volunteers had not been submitted to a procedure of familiarization with the equipment and the kind of exercise proposed. Familiarization can be understood as previous execution of a test procedure in order to reduce intra-subject variation (CURRELL; JEUKENDRUP, 2008). Despite being physically active, the volunteers knew the proposed exercise in the isoinertial dynamic form but they were not familiar with the exercise in the isometric form and maximum intensity. If the load of a session is not enough to promote significant physiologic and morphologic adaptation, it is supposed that the volunteers created coordinative strategies in an attempt to reach the aim on the retest step. This hypothesis is reinforced by the fact that retest performance was higher for all variables evaluated in relation to test performance.

The importance of familiarization sessions aiming to obtain more accurate results has been reported in other studies (CLAUDINO et al., 2013; WALDRON; HIGHTON; GRAY, 2016; VRBIK et al., 2017). Ploutz-Snyder and Giamis (2001), when analyzing the familiarization process with the 1-RM test, found significant increases in muscular strength $(\mathrm{p}<0.05)$, both in young women $(12 \% ; \mathrm{n}=7)$ and older women $(22 \% ; n=6)$. However, the number of familiarization sessions needed to load stabilization was lower for young women when compared to the older women (3-4 and 8-9 sessions, respectively). Even so, it was observed that for young people four familiarization sessions with a maximum strength test were necessary. 
Using the same procedure of comparison between test and retest, Gerodimos et al. (2015) tested the reliability of hip adduction and abduction strength using isokinetic equipment. The authors found ICC values from moderate to high between the test and retest for evaluating the maximum torque and the ratios of mutual muscular groups $(\mathrm{ICC}=0.71-0.92 ;$ ICC $=0.44-0.87$, respectively $)$, while the bilateral torque relation (asymmetry) reported low to moderate reliability (ICC $=0.11$ 0.64). These findings show that even using equipment considered the "gold-standard" for strength measurement, low to moderate ICC values were achieved in certain variations, indicating the hazards of evaluating the hip adductor and abductor muscular groups and the need for familiarization with the task.

When comparing the results obtained by Gerodimos et al. (2015) with those from this research, it is even possible to identify that in both, the rates with lower reliability were those associated with strength imbalance. This result was expected, once the errors on the strength measures are summed to the errors on the imbalance measures.

Unfortunately, there is a lack of research concerning the reliability of the procedures for measuring strength of hip adduction and abduction, especially using dynamometers that differ from isokinetic ones. Overall, manual dynamometers have been used in scientific research in order to evaluate the strength level of the hip joints, especially the abductors. Bittencourt et al. (2016) referenced values for the maximum isometric torque of the hip abductors using a manual dynamometer on young athletes involved in futsal, volleyball, and basketball. Their results indicate that gender, age, and the kind of sport practiced influence the hip abductor torques. Athletes aged from 15 to 19 years demonstrated higher abductor torques $(1.41 \pm 0.27$ $\mathrm{Nm} / \mathrm{kg})$ than athletes aged from 10 to 14 years $(1.12$ $\pm 0.21 \mathrm{Nm} / \mathrm{kg}$ ); those from the futsal and volleyball modalities had a higher torque than the basketball players (futsal: $1.34 \pm 0.37 \mathrm{Nm} / \mathrm{kg}, \mathrm{p}=0.001$; volleyball: $1.28 \pm 0.25 \mathrm{Nm} / \mathrm{kg}, \mathrm{p}=0.014$; basketball: $1.15 \pm 0.31 \mathrm{Nm} / \mathrm{kg}$ ); the torque values of the hip abductors were higher in the male athletes $(1.28 \pm 0.25 \mathrm{Nm} / \mathrm{kg})$ than the female athletes $(1.13 \pm$ $0.22 \mathrm{Nm} / \mathrm{kg}$ ).

Teixeira-Salmela et al. (2005) also used a manual dynameter to evaluate the hip abductor strength before and after a training protocol applied in hemiplegic individuals. The individuals achieved a gain of force in the hip abductors of the affected limb (pre: $104.95 \pm 47.34$ - post: $127.91 \pm 57.31$ $25 \%$ gain) and in the non-affected limb (pre: 128.17 \pm 46.35 - post: $153.17 \pm 45.04-29 \%$ gain). However, neither Teixeira-Salmela et al. (2005) nor Bittencourt et al. (2016) mentioned the reliability of the measuring procedures utilized. In these cases, the information concerning reliability would provide a better warranty that the increase in performance had resulted from the intervention applied, and not only a process of learning the task due to repetition, in Teixeira-Salmela et al. (2005) research case, and in the reliability of cut-off points suggested by Bittencourt et al. (2016).

This study has limitations that should be considered. Although the sample is experienced with strength training (at least six months of practice), subjects may be inexperienced in isometric exercises and / or in the adductor and abductor bench exercises. This fact leads to the main limitation of the study, the lack of familiarity with hip adductor and abductor isometric maximal strength tests. Moreover, it is noteworthy that a larger sample is recommended in future studies, especially when using the variable rate of force development, which tends to present greater dispersion between subjects. So, the results presented in the research point to the need to include a familiarization system in order to measure the maximum isometric strength of hip adductors and abductors and also, reaffirm the importance of proposing more affordable tests, although trustworthy ones, which evaluate the hip adductor and abductor muscles. The availability of affordable tests may contribute to physical education professionals and physiotherapists in having more tools to identify inadequate strength levels that might harm hip joint stability, contributing in the latter case, to preventing injuries caused by poor posture.

\section{CONCLUSION}

The methodology employed for evaluating the hip adductors and abductors was shown not to be reliable in most of the parameters investigated. The performance on retest was higher than the performance on the initial test. These results indicate that the muscles of the hip joints, in particular the adductors and abductors, are complex structures to be analyzed and need previous familiarization with the proposed exercise, once they are not habitually performed. 
RESUMO: O presente estudo teve como objetivo avaliar a confiabilidade de um teste para avaliação da força e desequilíbrios de força de abdutores e adutores de quadril utilizando um equipamento isoinercial adaptado para isometria. Participaram do estudo 13 sujeitos saudáveis, do sexo masculino, fisicamente ativos. Foram realizados dois testes isométricos unilaterais utilizando uma célula de carga fixada em um banco abdutor adaptado: teste de Abdução de Quadril e Teste de Adução de Quadril. Os testes consistiram em duas contrações isométricas voluntárias máximas de seis segundos de duração com intervalo de um minuto entre elas. As seguintes variáveis dinâmicas foram avaliadas: Força Máxima, Força Média, Taxa de Produção de Força, para cada membro (direito e esquerdo), e a existência de assimetrias entre membros. Para análise estatística foram realizados teste $t$, coeficiente de correlação intraclasse $(C C I)$ e erro padrão de medida. Resultados: A metodologia empregada para avaliação de adutores e abdutores de quadril não se mostrou confiável na maioria dos parâmetros investigados, com valores de CCI não significativos ou baixos, e o desempenho no reteste foi superior ao teste $(\mathrm{p}<0,05)$. O teste empregado não se mostrou confiável para avaliação da força e desequilíbrios de força de abdutores e adutores do quadril na maioria dos parâmetros investigados . Esses resultados demonstram que a articulação do quadril, mais precisamente os músculos abdutores e adutores, são estruturas complexas de se avaliarem, necessitando de uma familiarização prévia com o exercício proposto, por não serem movimentos realizados habitualmente. Recomenda-se novos testes para avaliação da força de adução e abdução de quadril adicionando um procedimento de familiarização prévio.

PALAVRAS-CHAVE: Isometria. Célula de Carga. Dinamometria de Força Muscular. Coeficiente de Correlação Intraclasse.

\section{REFERENCES}

ALVARES, J. B. D. A. R.; RODRIGUES, R.; DE AZEVEDO FRANKE, R.; DA SILVA, B. G. C.; PINTO, R. S.; VAZ, M. A.; BARONI, B. M. Inter-machine reliability of the Biodex and Cybex isokinetic dynamometers for knee flexor/extensor isometric, concentric and eccentric tests. Phys Ther Sport, v. 16, n. 1, p. 59-65, 2015. https://doi.org/10.1016/j.ptsp.2014.04.004

BITTENCOURT, N. F. N.; SANTOS, T. R. T.; GONÇALVES, G. G. P.; COELHO, A. P.; GOMES, B. G. B. DE M.; MENDONÇA, L. D. M.; FONSECA, S. T. Reference values of hip abductor torque among youth athletes: Influence of age, sex and sports. Phys Ther Sport, v. 21, p. 1-6, 2016.

https://doi.org/10.1016/j.ptsp.2015.12.005

CLAUDINO, J. G.; MEZÊNCIO, B.; SONCIN, R.; FERREIRA, J. C.; VALADÃO, P. F.; TAKAO, P. P.; BIANCO, R.; ROSCHEL, H.; AMADIO, A. C.; SERRÃO, J. C. Desenvolvimento de um método de familiarização individualizado para saltos verticais. Rev Bras Med Esporte, v. 19, n. 5, p. 359-362, 2013. https://doi.org/10.1590/S1517-86922013000500012

CURRELL, K.; JEUKENDRUP, A. E. Validity, Reliability and Sensitivity of Measures of Sporting Performance. Sports Med, v. 38, n. 4, p. 297-316, 2008. https://doi.org/10.2165/00007256-200838040-00003

FERREIRA J. C.; ARAÚJO, S. R. S.; PIMENTA, E. M.; MENZEL, H. K.; MEDEIROS, F. B.; ANDRADE, A. G.; OCARINO, J. M.; CHAGAS, M. H. Impact of competitive level and age on the strength and asymmetry of young soccer players. Rev Bras Med Esporte, v. 24, n. 5, p. 357-360, 2018. https://doi.org/10.1590/1517869220184985

GERODIMOS, V.; KARATRANTOU, K.; PASCHALIS, V.; ZAFEIRIDIS, A.; KATSARELI, E.; BILIOS, P.; KELLIS, S. Reliability of concentric and eccentric strength of hip abductor and adductor muscles in young soccer players. Biol Sport, v. 32, n. 4, p. 351-356, 2015. https://doi.org/10.5604/20831862.1189202

HAFF, G. Gregory et al. A comparison of methods for determining the rate of force development during isometric midthigh clean pulls. J Strength Cond Res, v. 29, n. 2, p. 386-395, 2015.

https://doi.org/10.1519/JSC.0000000000000705 
MAGALHÃES, J.; OLIVEIRA, J.; ASCENSÃO, A.; SOARES, J. Concentric quadríceps and hamstring isokinetic strength in volleyball and soccer players. J Sport Med Phys Fit, v. 44, p. 119-125, 2004.

MARTIN, H. J.; YULE, V.; SYDDALL, H. E.; DENNISON, E. M.; COOPER, C.; AIHIE SAYER, A. Is Hand-Held Dynamometry Useful for the Measurement of Quadriceps Strength in Older People? A Comparison with the Gold Standard Biodex Dynamometry. Gerontology, v. 52, n. 3, p. 154-159, 2006.

https://doi.org/10.1159/000091824

MCCURDY, K.; LANGFORD, G. The relationship between maximum unilateral squat strength and balance in young adult men and women. J Sport Sci Med, v. 5, n. 2, p. 282-8, 2006.

MITCHELL, U. H. JOHNSON, A. W.; VEHRS, P. R.; FELAND, J. B.; HILTON, S. C. Performance on the Functional Movement Screen in older active adults. J Sport Health Sci, v. 5, n. 1, p. 119-125, 2016. https://doi.org/10.1016/j.jshs.2015.04.006

PANNI, A. S.; BIEDERT, R. M.; MAFFULLI, N.; TARTARONE, M.; ROMANINI, E. Overuse injuries of the extensor mechanism in athletes. Clin Sports Med, v. 21, n. 3, p. 483-498, 2002.

https://doi.org/10.1016/S0278-5919(02)00028-5

PLOUTZ-SNYDER, L. L.; GIAMIS, E. L. Orientation and familiarization to 1RM strength testing in old and young women. J Strength Cond Res, v. 15, n. 4, p. 519-23, 2001. https://doi.org/10.1519/00124278200111000-00020

SAHRMANN, S. S. Diagnosys and Treatment of movement impairment syndromes. St Louis: Mosby, 2002. $380 \mathrm{p}$.

SIQUEIRA, C. M.; PELEGRINI, F. R. M. M.; FONTANA, M. F.; GREVE, J. M. D. Isokinetic dynamometry of knee flexors and extensors: comparative study among non-athletes, jumper athletes and runner athletes. Rev Hosp Clín, v. 57, n. 1, p. 19-24, fev. 2002. https://doi.org/10.1590/S0041-87812002000100004

TEIXEIRA-SALMELA, L. F.; LIMA, L. A. O.; MORAIS, S. G.; GOULART, F. Assimetria e Desempenho Funcional em Hemiplégicos Crônicos antes e após programa de treinamento em academia. Rev Bras Fisioter, v. 9, n. 2, p. 227-233, 2005.

VASCONCELOS, R. A.; BEVILAQUA-GROSSI, D.; SHIMANO, A. C.; PACCOLA, C. J.; SALVINI, T. F.; PRADO, C. L.; MELLO JUNIOR, W. A. Confiabilidade e validade de um dinamômetro isométrico modificado na avaliação do desempenho muscular em indivíduos com reconstrução do ligamento cruzado anterior. Rev Bras Ortop, v. 44, n. 3, p. 214-224, jun. 2009. https://doi.org/10.1590/S0102-36162009000300007

VRBIK, I.; SPORIS, G.; STEFAN, L.; MADIC, D.; TRAJKOVIC, N.; VALANTINE, I.; MILANOVIC, Z. The influence of familiarization on physical fitness test results in primary school-aged children. Pediatr Exer Sci, v. 29, n. 2, p. 278-284, 2017. https://doi.org/10.1123/pes.2016-0091

WALDRON, M.; HIGHTON, J; GRAY, A. Effects of familiarization on reliability of muscle-activation and gross efficiency in adolescents and adults. Cogent Medicine, v. 3, n. 1, p. 1-13, 2016.

https://doi.org/10.1080/2331205X.2016.1237606

WITVROUW, E.; DANNEELS, L.; ASSELMAN, P.; D’HAVE, T.; CAMBIER, D. Muscle Flexibility as a Risk Factor for Developing Muscle Injuries in Male Professional Soccer Players. Am J Sports Med, v. 31, n. 1, p. 41-46, 30 jan. 2003. https://doi.org/10.1177/03635465030310011801 